\title{
CAPITULO 5 \\ REINTEGRAÇÃO DO RIO CRICIÚMA NA PAISAGEM URBANA: UM PRIMEIRO OLHAR
}

DOI: http://dx.doi.org/10.18616/pgt05

Rose Maria Adami Maurício Pamplona 


\section{INTRODUÇÃO}

Os rios e suas águas foram um fator primordial na escolha dos lugares para a sociedade humana se estabelecer, desde as antigas civilizações, em função das suas possibilidades de sobrevivência e estabilidade econômica e financeira. Esse elemento geográfico foi utilizado em diferentes países (BENÉVOLO 2001), inclusive no Brasil (PIAZZA; HÜBENER, 2003), por muitos modelos colonizadores, como eixo norteador na demarcação dos lotes coloniais, fazendo com que os vales fluviais passassem a exercer forte influência no plano urbano das colônias e posteriormente dos espaços urbanos consolidados.

O crescimento das cidades no entorno dos rios sem planejamento adequado e a especulação imobiliária beneficiou a expansão urbana em fundos de vales fluviais, cursos d'água e margens de rios, áreas com alto grau de fragilidade ambiental. Com a consolidação das cidades, a falta de saneamento, de coleta e tratamento de esgotos domésticos e industriais, as águas dos rios do meio urbano passaram a ser consideradas como problemas para a saúde e a segurança da população.

$\mathrm{Na}$ grande maioria das vezes, os gestores públicos realizaram obras estruturais de canalizações e aterramento dos rios, suas margens e áreas alagadiças, como soluções para os problemas de saneamento, tendo como base o modelo higienista. Todavia, além de descaracterizar e/ou eliminar os rios da paisagem urbana, as obras estruturais agravaram as inundações urbanas e comprometeram o ecossistema que dependiam das águas dos rios.

O desaparecimento desses cursos d'água da paisagem contribuiu para a falta de preocupação em recuperá-los e integrá-los ao espaço urbano. A degradação dos rios é uma condição observada em todos os países, independente das suas condições econômicas. $\mathrm{Na}$ grande maioria das cidades brasileiras, os rios que estão presentes no perímetro urbano, de alguma forma, apresentam-se degradados com intervenções no seu leito e margens. 
Nos últimos anos, alguns países americanos, europeus e asiáticos, depois de terem canalizados os rios do espaço urbano, iniciaram um processo ao contrário, ou seja, de revitalizar e/ou reintegrar seus rios à paisagem urbana (MACHADO et al., 2010). A revitalização de rios e córregos, que no passado foram canalizados em função do modelo higienista, é uma tendência mundial crescente em cursos d'água urbanos em diversos países, inclusive no Brasil. A ideia de revitalização dos rios brasileiros está na fase inicial, mas já existem ações em algumas cidades da federação, principalmente em Minas Gerais (GOMES, 2010; SALLES FILHO, 2010) e São Paulo (GORSKI, 2010).

Para impulsionar a ideia de revitalização dos rios brasileiros, o Governo Federal criou, por meio do Decreto Presidencial n. 6.101/2007, - Departamento de Revitalização de Bacias Hidrográficas (DRB), que é vinculado à Secretaria de Recursos Hídricos e Ambiente Urbano, com o objetivo de definir estratégias para a implementação de programas e projetos com temas relacionados à recuperação e à revitalização de bacias hidrográficas. A revitalização proposta pelo Governo Federal visa ações integradas e permanentes para a promoção do uso sustentável dos recursos naturais, da melhoria das condições socioambientais, do aumento da quantidade e da qualidade da água para usos múltiplos, em programas e projetos organizados, tendo como base as bacias hidrográficas, localizadas nas doze regiões hidrográficas nacionais (BRASIL, 2017).

A revitalização de rios e córregos em meio urbano, todavia, é um assunto que desafia os gestores públicos e provoca muitos debates, a iniciar pela sua conceituação, pois Sepúlveda $(2010$, p. 16) enfatiza que "não se pode chamar de revitalização um canal aberto de concreto com taludes laterais inclinados com vegetação de gramíneas e arbustos". É preciso definir de forma coletiva: "qual a revitalização que se quer?" Para o autor, a revitalização em ambientes urbanos "passa pela criação de condições para que a vida possa existir nesses ambientes, seja na manutenção ou na recuperação da biota aquática".

Mas, para que os rios urbanos possam voltar a ter condições de vida no seu ambiente, o segundo desafio é despertar nos gestores pú- 
blicos e na própria população o interesse de integrar os cursos d'água à paisagem urbana, pois esses dois segmentos da sociedade são de suma importância a fim de que o processo de revitalização dos rios realmente aconteça. Os gestores públicos têm o papel fundamental de incorporar os rios ao espaço urbano nos planos diretores e nos projetos e ações desse processo de planejamento de forma integrada. A população, de forma geral, precisa ser educada ambientalmente para conviver com os cursos d'água no meio urbano. É preciso convencer a população que esse elemento geográfico é um patrimônio cultural, pois faz parte da história social e econômica da cidade, e, em função disso, precisa ser reconectado à cidade.

O terceiro desafio aos gestores públicos é a implantação da coleta e tratamento de esgotos domésticos e industriais nos rios urbanos, enquanto ação político-administrativa, juntamente com as empresas de saneamento contratadas pelas prefeituras, para despoluição e recuperação da qualidade da água, redução do mau cheiro e de problemas de saúde da população.

O rio Criciúma, localizado no extremo sul de Santa Catarina, corta a área mais densamente povoada do perímetro urbano do município de Criciúma, com uma extensão aproximada de 7 km (Figura 1). Esse rio, no período do processo de colonização, final do século IXX, foi o principal elemento geográfico que auxiliou na divisão dos primeiros lotes coloniais. 
Figura 1 - Localização da bacia do rio Criciúma e da área de estudo no município de Criciúma

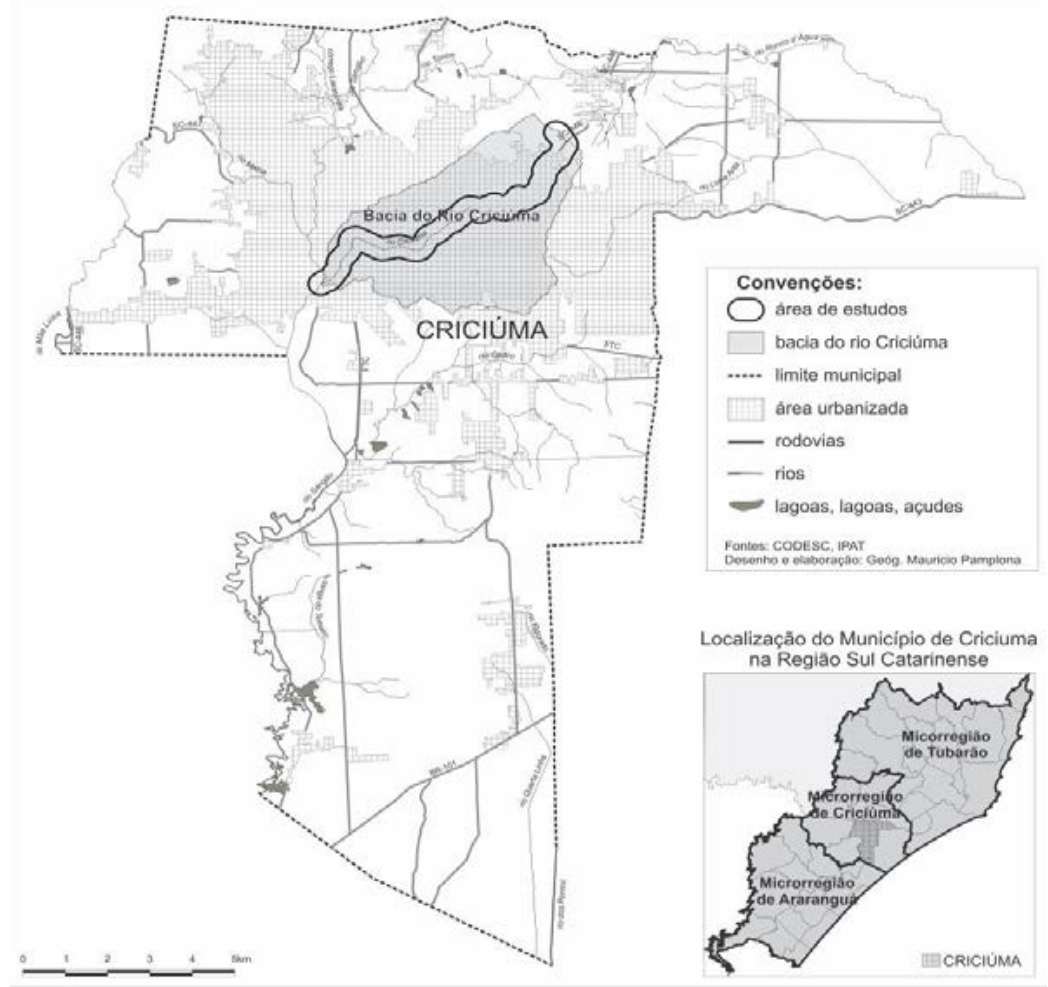

Fonte: CODESC e IPAT

Nas primeiras décadas do século $\mathrm{XX}$, quando a cidade avançou sobre as margens do rio Criciúma e não havia saneamento para os esgotos domésticos, industriais, drenagens ácidas das minas de carvão e suas águas inundavam os lotes nos períodos das precipitações intensas, o rio Criciúma se transformou em "uma ameaça" à saúde e à segurança dos habitantes da cidade. Para sanar esse "problema ambiental e urbano", a partir do início dos anos de 1960 iniciaram as intervenções no rio Criciúma e suas margens, por meio de canalizações, que praticamente o eliminaram da paisagem urbana (ADAMI, 2015). 
Na linha da revitalização que algumas cidades internacionais e nacionais adotaram nos últimos anos para seus rios urbanos, este artigo tem como objetivo propor um primeiro olhar para reintegração do rio Criciúma na paisagem urbana do município.

\section{A CENTRALIDADE HISTÓRICA: O RIO CRICIÚMA COMO NORTEADOR DO ESPAÇO URBANO}

O rio Criciúma, principal rio da bacia hidrográfica urbana do município de mesmo nome, encontra-se na área mais densamente povoada do perímetro urbano do município. Adami (2015), baseada no censo do Instituto Brasileiro de Geografia e Estatística (IBGE) de 2010, mostra que na bacia do rio Criciúma há uma densidade demográfica de 3.453 habitantes por $\mathrm{km}^{2}$, sendo que cerca de $33,3 \%$ do total de habitantes do município vivem na bacia hidrográfica.

O crescimento urbano desordenado no entorno do rio Criciúma ocorreu porque desde o início do processo colonizador até meados dos anos 1930 o rio foi o eixo norteador, usado pelo modelo colonizador como direcionador da divisão fundiária, e a ocupação se estendia até as encostas dos divisores de água da bacia do rio Criciúma. Era um período em que o rio Criciúma tinha muito a oferecer para a população, pois orientava caminhos que mais tarde se transformaram em estradas. As suas águas saciavam a sede da população e dos animais, forneciam alimentação (pesca) para a população, possibilitavam a higiene pessoal, o lazer, a limpeza de roupas e dos utensílios domésticos, além de fornecer força motriz para girar as rodas d'água dos engenhos, a fim de atender às necessidades das primeiras indústrias de manufatura do município (ADAMI, 2015).

Criciúma, na primeira década do século XX, era uma cidade pacata, mesmo com os incentivos do governo federal para criação das primeiras empresas de exploração de carvão mineral da União e de particulares. Todavia, nas décadas seguintes, até o final dos anos de 1970, com a permanência do incentivo governamental para exploração de carvão, houve um processo 
migratório significativo para o município e muitos profissionais ligados à exploração e beneficiamento desse minério se deslocaram de vários lugares do país para Criciúma, a fim de dar assistência às empresas mineradoras. Também migraram de municípios no entorno de Criciúma muitos pescadores e agricultores, juntamente com suas famílias, para trabalhar nas minas de carvão. Além dessa demanda vinculada diretamente ao processo de exploração e de beneficiamento de carvão, houve a migração de muitos profissionais de diversas áreas para atender às atividades de serviços e comércio do município (ADAMI, 2015).

Para atender toda essa demanda populacional, em tão pouco tempo, houve uma segregação populacional de classes sociais. Os técnicos vinculados à exploração e beneficiamento de carvão e os profissionais de diversas áreas relacionadas às atividades de serviços e comércio foram morar na parte central do município, no alto vale da bacia do rio Criciúma (curso superior), e os trabalhadores das minas residiam em vilas operárias construídas pelas empesas de mineração, no entorno das minas de carvão, muitas delas localizadas no médio e baixo vale da bacia (cursos médio e inferior do rio). Com esses rearranjos habitacionais, houve muitas mudanças na paisagem da bacia hidrográfica e o rio Criciúma e seus afluentes foram alterados de forma direta no canal fluvial, com as retilinizações, aterros, contenção de margem, de fundo e tamponamento do leito, principalmente a partir dos anos de 1960; e, de forma indireta, com as construções e impermeabilizações nas suas margens (ADAMI, 2015).

A espacialização da ocupação urbana da bacia do rio Criciúma apresentada nos mapas dos anos de 1956 (Figura 2), 1978 e 2007, mostram que até 1956 a malha urbana da época estava condicionada ao rio Criciúma e esse se apresentava meandrante, sem intervenções de forma direta no canal fluvial. No entanto, as intervenções concentravam-se nas suas margens, principalmente na área central, com a retirada da mata ciliar e ocupações das margens do rio, as atuais áreas de preservação permanente. Nos cursos médio e inferior do rio, as ocupações se restringiam a poucos arruamentos, nos atuais bairros de Operária Nova, Santa Barbara e Santo Antônio. Todavia, a partir desses bairros havia caminhos que os ligavam ao maciço do morro Cechinel, 
que nos anos posteriores se transformaram em arruamentos consolidados. $\mathrm{O}$ mesmo aconteceu nos caminhos, em direção aos atuais bairros Santa Barbara e Pinheirinho.

Vinte e dois anos depois, em 1978 (Figura 3), o rio Criciúma sofreu intervenções ambientais e urbanas, ao longo de toda a sua extensão, e seu leito outrora meandrante foi retilinizado e as curvas do rio foram aterradas com rejeito de beneficiamento de carvão. A partir dessas intervenções realizadas pelo poder público e por parte da população, o rio se transformou no principal meio de escoamento dos esgotos domésticos, industriais, das águas ácidas das minas e dos lavadores de carvão e de parte dos resíduos sólidos produzidos na área central (ADAMI, 2015).

Figura 2 - Espacialização da ocupação urbana no entorno do rio Criciúma no ano de 1956

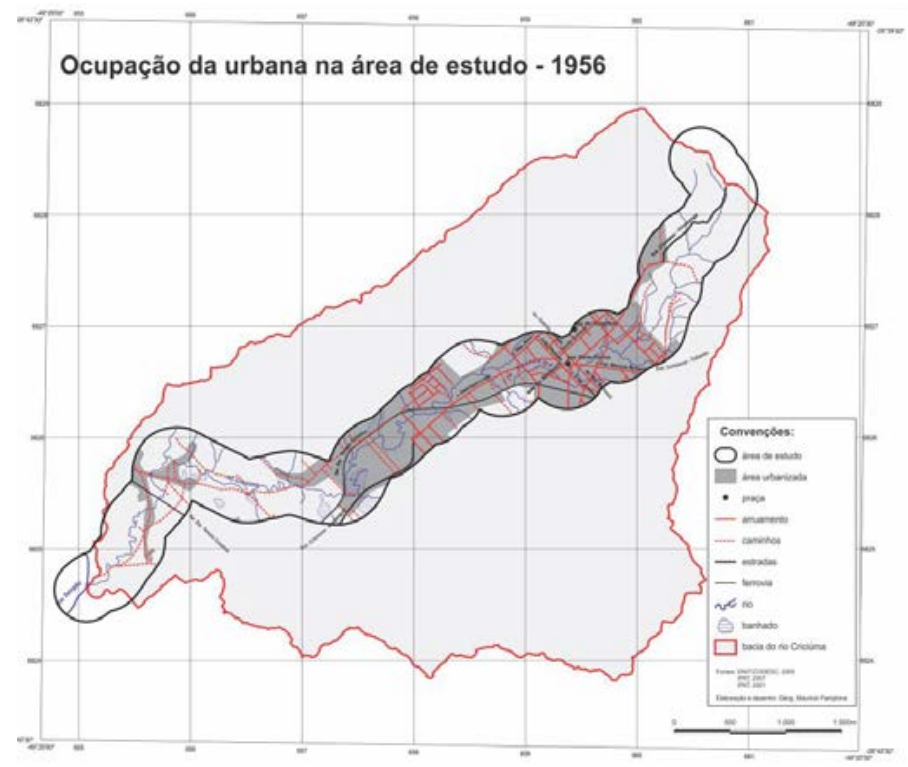

Fonte: Adaptada de Adami (2015).

$\mathrm{Na}$ área central da bacia (curso superior), o rio Criciúma foi canalizado, com contenção de margens e de fundo. Em grande parte da sua 
extensão foi tamponado e sobre seu leito e suas margens foram realizadas edificações. Nos cursos médio e inferior do rio Criciúma, as mudanças na paisagem foram mais significativas, pois praticamente em toda essa extensão as margens do rio Criciúma foram ocupadas. No entanto, essas ocupações, em grande parte da extensão, apresentam certo recuo entre o rio e as construções (ADAMI, 2015).

Nos anos de 2007 e nas décadas seguintes (Figura 4), o rio Criciúma praticamente desapareceu da paisagem, principalmente na parte central da cidade, em função do processo intenso de verticalização, em que o rio ficou confinado na parte de traz dos prédios, residências e estabelecimentos comerciais. Nesse espaço, na grande maioria dos lotes, as construções mais antigas não se adequaram à lei municipal de Parcelamento de Solo aprovada em 1999, que instituiu para o rio Criciúma e seus afluentes, desde as suas nascentes até a rua Henrique Lage, uma faixa não edificável, de 5 metros para cada lado de sua margem.

Figura 3 - Espacialização da ocupação urbana no entorno do rio Criciúma no ano de 1978

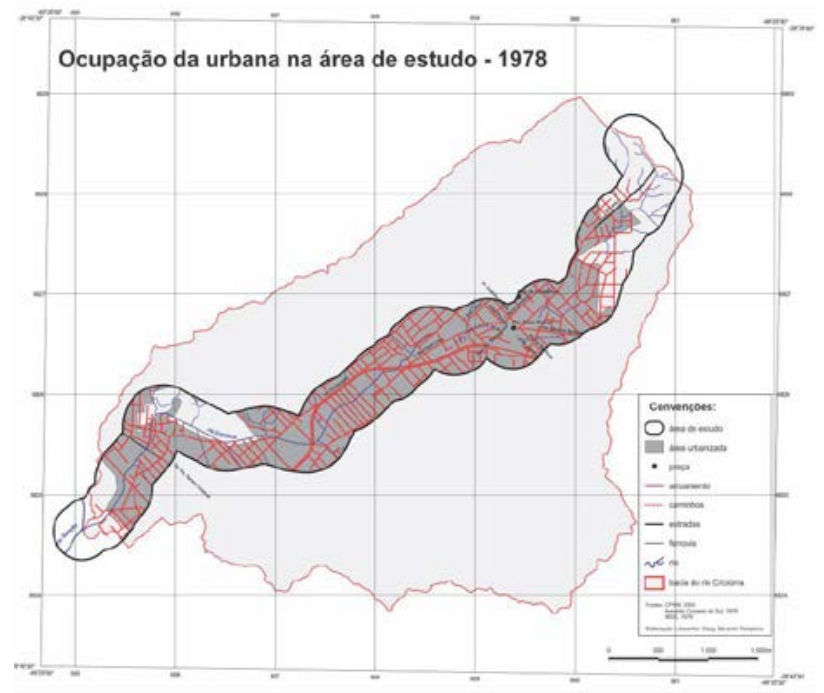

Fonte: Adaptada de Adami (2015). 
Em outros lotes, percebe-se que há certo recuo entre as construções e as margens do rio, deixando o rio enclausurado no interior das quadras e suas margens ocupadas por vários usos urbanos. Depois do cruzamento da rua Henrique Lage com a Avenida Centenário, a lei de Parcelamento de Solo amplia a sua área não edificável para uma faixa de 15 metros ao longo do rio. Nesse trecho, o uso que se faz das terras ao longo do rio é predominantemente residencial, com algumas edificações comerciais consolidadas. Determinadas habitações são irregulares, pois não respeitam a faixa não edificável próxima do rio (ADAMI, 2015).

Desde o início dos anos de 1960 até os dias atuais, o município foi omisso com relação à implementação de legislações que realmente protegessem as áreas de preservação permanente do rio Criciúma. Os Planos Diretores de 1973 e 1984 foram omissos com relação às faixas marginais de proteção dos rios. O Plano Diretor de 1999 institui uma faixa de proteção das margens dos rios de 30 metros, seguindo o Código Florestal vigente.

Figura 4 - Espacialização da ocupação urbana no entorno do rio

Criciúma no ano de 2007

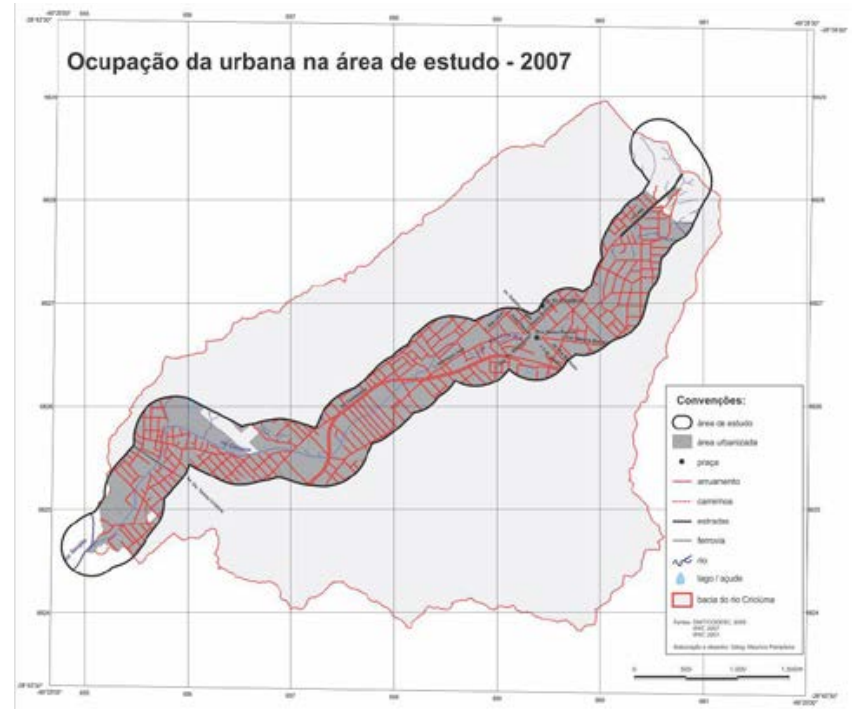

Fonte: Adaptada de Adami (2015). 
No entanto, neste mesmo ano foi instituída a Lei de Parcelamento do Solo, que estabelecia no seu Artigo $5^{\circ}$ uma faixa de proteção de cinco e 15 metros ao longo do rio Criciúma e seus afluentes. Segundo a Lei, não era permitido edificar no "Rio Criciúma e seus afluentes numa faixa de 5 metros para cada lado de sua margem, iniciando na sua nascente, até encontrar a rua Henrique Lage". Após o cruzamento da rua Henrique Lage com a Avenida Centenário, a lei institui no seu Artigo $5^{\circ}$ a não permissão do parcelamento do solo para uma faixa de 15 metros. É possível perceber que não há consonância entre esses dois documentos, com relação à faixa de proteção dos cursos d'água do município. No Plano Diretor seguinte, aprovado em 2012, no Artigo 22ㅇ das diretrizes gerais do plano se propõe a preservar, proteger e fiscalizar as margens ainda não ocupadas de diversos rios entre eles o rio Criciúma, assim como proteger as áreas de preservação dos diversos morros do município entre eles os morros do Céu e Cechinel. Todavia, o documento não define a metragem a ser respeitada.

Na imagem captada em 2017 (Figura 5), é possível observar que há no rio Criciúma intervenções ambientais e urbanas, em toda a sua extensão. Existe uma heterogeneidade de características ao longo da extensão do rio. No curso superior, onde a área é mais urbanizada por edificações residenciais, comerciais e de serviços, há pouca permeabilidade do solo, e o rio corre canalizado nos fundos de lotes, entre as quadras, passando despercebido pelos moradores e visitantes da cidade.

Essa ocupação do espaço urbano de forma desordenada possibilitou que as áreas antes ocupadas pelo rio Criciúma e suas margens, depois de recobertas, fossem transformadas em espaços de uso privado. No curso médio e inferior, o uso da terra ao longo do rio é predominantemente residencial, combinado com alguns vazios urbanos, habitações irregulares de classe média e baixa e edificações comerciais consolidadas. 
Figuras 5 - Espacialização da ocupação urbana no entorno do rio Criciúma no ano de 2017

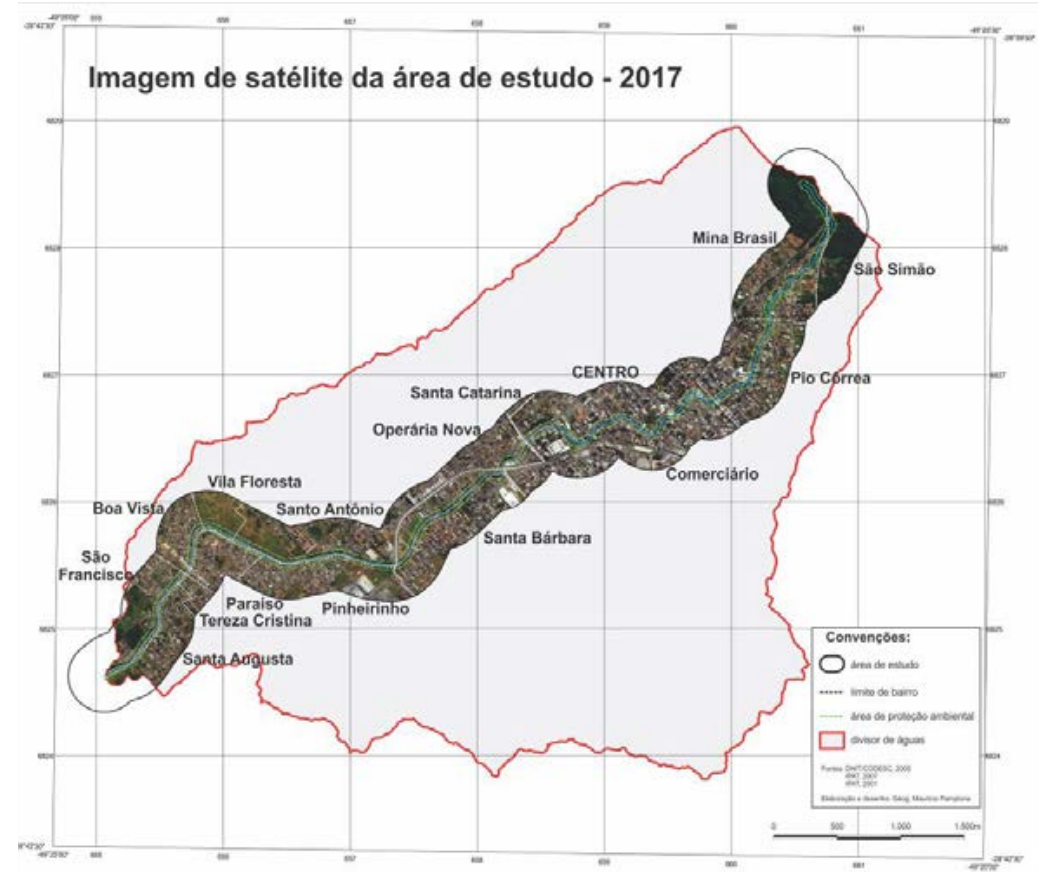

Fonte: Adaptada do Bing Maps 2017.

Na análise da imagem de 2017, percebe-se que o padrão de estruturação urbana estabelecido no município com as obras estruturais realizadas ao longo dos anos provocou significativa degradação ambiental nos cursos d'água, em função da ocupação intensiva e irregular de áreas do leito do rio e suas margens, além de ter resultado em uma elevada impermeabilização do solo urbano e na contaminação dos cursos d'água, áreas ambientalmente frágeis, em razão da ausência de uma rede de coleta e tratamento de esgoto, implementada somente no início dos anos de 2010. 


\section{REINTEGRAÇÃO DO RIO CRICIÚMA NA PAISAGEM URBANA}

$\mathrm{Na}$ linha da revitalização dos rios urbanos que algumas cidades nacionais e internacionais adotaram nos últimos anos, escolheu-se o rio Criciúma como tema de uma proposta de reintegração do rio com a paisagem urbana. A proposta foi realizada para os participantes da oficina chamada "Rio Criciúma: Possibilidades de Associação ao Planejamento, Paisagismo e Urbanismo", proferida no VIII Seminário de Pesquisa em Planejamento e Gestão Territorial (SPPGT), com o tema "A Sustentabilidade dos Ecossistemas Urbanos", que ocorreu em setembro de 2017 na Universidade do Extremo Sul Catarinense, em Criciúma, Extremo Sul de Santa Catarina.

A oficina foi baseada no livro intitulado Rio Criciúma: o Rio que a Cidade Escondeu - Significados e Representações, de Rose Maria Adami, lançado em 2015. A autora fez uma explanação sobre a evolução histórica da apropriação do rio Criciúma e seus afluentes pelos diferentes grupos sociais que colonizaram Criciúma e sobre o planejamento do espaço urbano do município. A partir desse conhecimento, os participantes foram desafiados a apresentar propostas de reintegração do rio Criciúma na paisagem urbana, a exemplo de alguns países da América, Europa, Ásia, inclusive o Brasil, que desde os anos de 1980 revitalizam seus cursos d'água urbanos.

Para o desenvolvimento das propostas, o rio Criciúma foi dividido em dois trechos: o primeiro abrangeu as nascentes do rio Criciúma, no maciço do morro Cechinel, até a rua Henrique Lage, travessa com a Av. Centenário; o segundo abrangeu a travessa com a Av. Centenário, até a confluência do rio Criciúma, com o rio Sangão, no bairro Santa Augusta. Nesses trechos, os participantes da oficina, divididos em dois grupos compostos por arquitetos, geógrafos e engenheiros ambientais, puderam discutir e apresentar propostas de reintegração do rio no meio urbano de Criciúma. Os grupos embasaram suas propostas de revitalização em 
imagem do Bing Maps de parte do rio Criciúma desde as suas nascentes até a foz, recortada por um buffer de 250 metros a partir das margens do rio Criciúma.

No primeiro trecho, o rio Criciúma passa pela parte mais populosa e verticalizada do município, e seu leito e suas margens encontram-se, na sua grande maioria, recobertos e impermeabilizados pela malha urbana, com arrumamentos, construções e edificações. O grupo encarregado da reintegração do rio Criciúma com a paisagem urbana nesse espaço propôs, depois de várias discussões e ideias (Figura 6), a revitalização de parte do rio, o restabelecimento parcial das características ambientais das margens e infraestrutura urbana para o acesso da população, entre as quadras das ruas Anita Garibaldi, avenida Centenário, rua Álvaro Catão e rua Araranguá (Figura 7), em que o rio encontra-se com contenção de margem e de fundo, localizado nos fundos das edificações.

Figura 6 - Levantamento de ideias para elaboração da proposta 1

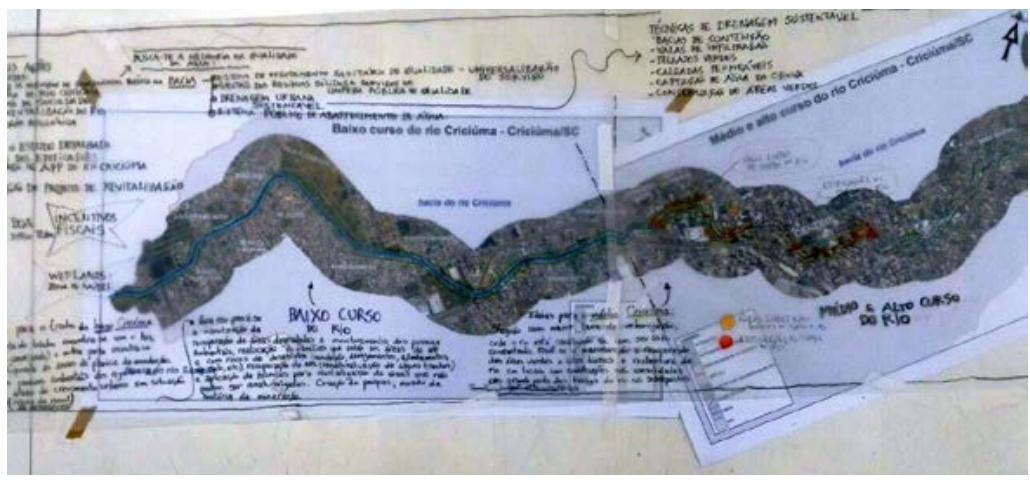

Fonte: Acervo dos autores

Para que a proposta seja efetivada, propôs-se a retirada de parte do tamponamento de concreto que recobre o rio Criciúma entre as quadras das ruas Anita Garibaldi, avenida Centenário, rua Vitório Serafim, até a rua Araranguá e retirada da impermeabilização de parte de suas margens; reconstituição da mata ciliar; efetivação em toda a 
bacia do rio Criciúma das ligações dos esgotos domésticos e industriais com a rede de esgoto, a coleta e o tratamento (Figura 8).

Figura 7 - Localização da área urbano da proposta 1

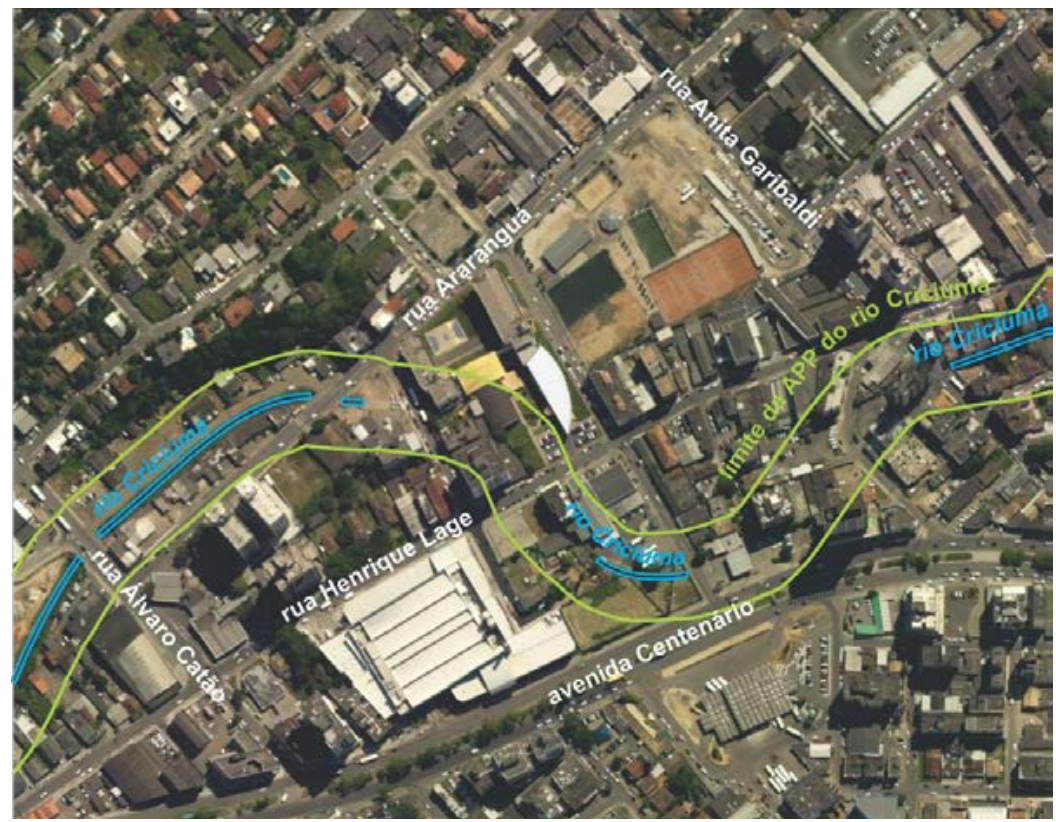

Fonte: Imagem adaptada do site SIGSC, Sistema de Informação Geográfica do

Estado de Santa Catarina, em 2017, htpp//www.sig.sds.sc.gov.br - acesso 25/04/2017.

Depois de "descoberto" o rio Criciúma, seria necessária a revitalização das suas margens, com patamares de contenção da água e para a aproximação das pessoas, além de infraestrutura adequada para a população poder usufruir do contato com o rio que passa no meio da cidade, como a iluminação, paisagismo e o plantio de árvores para o benefício da população e da fauna urbana. Tal proposta configura uma praça linear, a partir da continuidade nos espaços livres do entorno do rio, ou seja, 
as margens, quando consideradas áreas de preservação permanente (Figura 9).

Para a revitalização, não há necessidade de desapropriação das margens, pois grande parte do rio entre essas quadras se encontra com contenção de margem e de fundo, sem tamponamento e localizado nos fundos das edificações. Além do mais, nessa parte da cidade, a lei municipal de Parcelamento de Solo estabelece uma faixa de 5 metros não edificável, para cada lado do rio Criciúma.

Figura 8 - Proposta de revitalização de um trecho da área central no alto curso do rio Criciúma do grupo 1

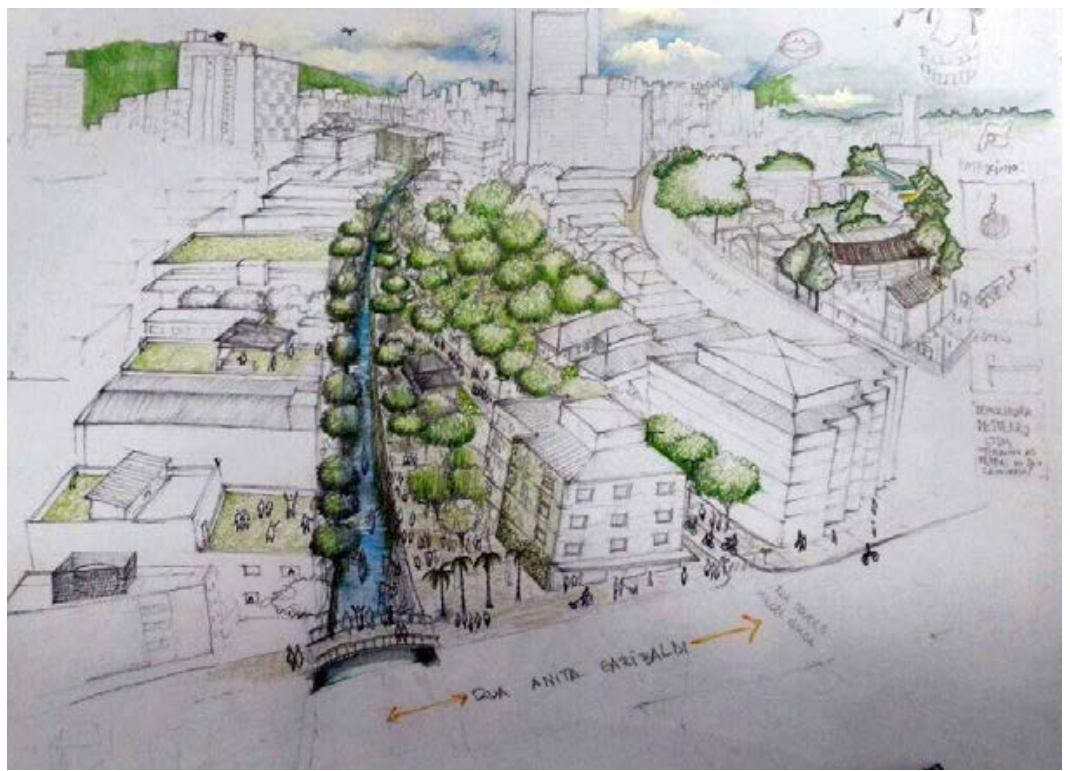

Fonte: Perceptiva elaborada a partir da proposta do grupo 1.

O segundo grupo ficou responsável pela proposta tendo como base a área da rua Henrique Lage, travessa com a avenida Centenário até a foz, com o rio Sangão, definido como médio e baixo curso do rio Criciúma. No médio curso, o rio encontra-se retilinizado, mas sem contenção de 
margens e de fundo e corta espaços ocupados por muitas edificações. Nas áreas mais próximas da foz (baixo curso), as edificações se distanciam um pouco do leito do rio, no entanto, a grande maioria dela não respeita os 15 metros estabelecidos pela Lei de Parcelamento do Solo. Nesse trecho, existem muitos vazios urbanos e algumas áreas são ocupadas por rejeito de beneficiamento de carvão, em processo de recuperação ambiental.

Figura 9 - Detalhes da proposta de revitalização de um trecho da área central no alto curso do rio Criciúma do grupo 1

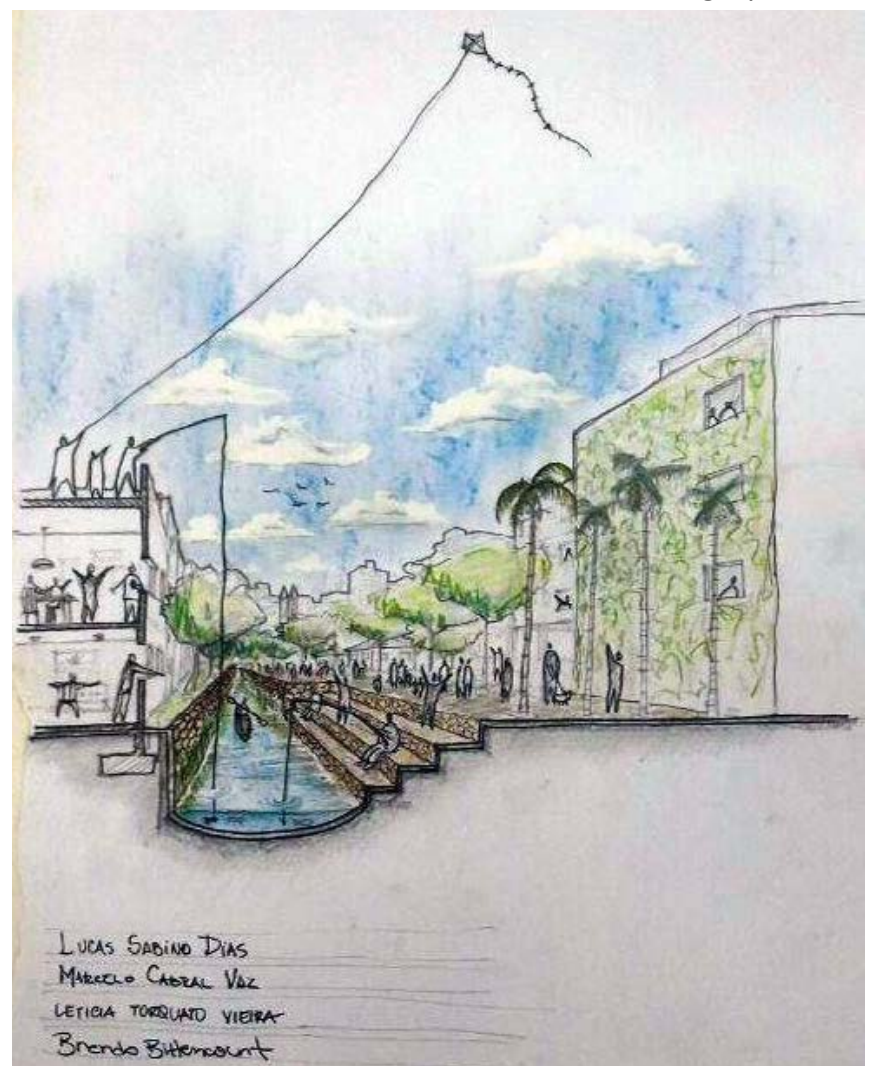

Fonte: Perceptiva elaborada a partir da proposta do grupo 1. 


\section{PLANEJAMENTO E GESTÃO TERRITORIAL}

O grupo encarregado da reintegração do rio Criciúma com a paisagem urbana, nesse trecho, propôs a revitalização de uma faixa de 15 metros de recomposição da mata ciliar em todo o trecho do rio, o restabelecimento das características ambientais das margens e a instalação de um parque com infraestrutura, acessível à população (Figura 10).

A proposta prevê a construção do parque em uma antiga área de rejeito de beneficiamento de carvão mineral recuperada, na margem direita do rio Criciúma, por empresas carboníferas, em função do Termo de Ajuste de Conduta (TAC), estabelecido a partir de uma ação civil pública do Ministério Público Federal, em 1993.

Figura 10 - Proposta de revitalização do médio e baixo curso do rio Criciúma do grupo 2

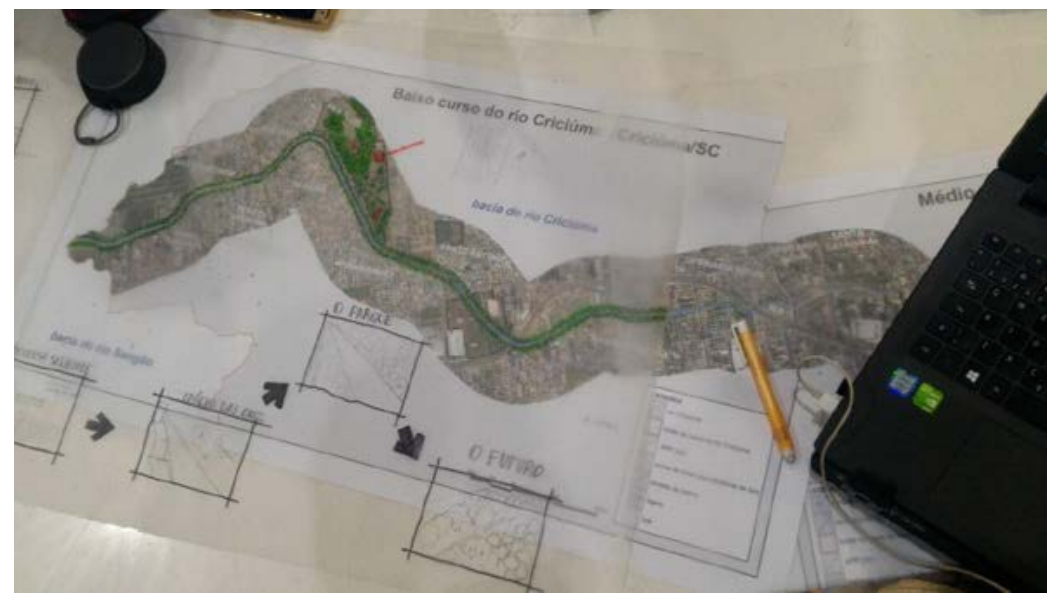

Fonte: Perceptiva elaborada a partir da proposta do grupo 2.

A recomposição da mata ciliar no entorno do rio Criciúma e a instalação do parque seria um plano de revitalização do rio, como proposta a ser discutida com a sociedade e com os legisladores, para incentivá-los a participar das diferentes etapas de execução dos projetos e também para conscientizá-los sobre a importância da integração do rio ao perímetro urbano pelo seu valor cultural e ambiental (Figura 11). 
Figura 11 - Proposta de revitalização do médio e baixo curso do rio Criciúma do grupo 2

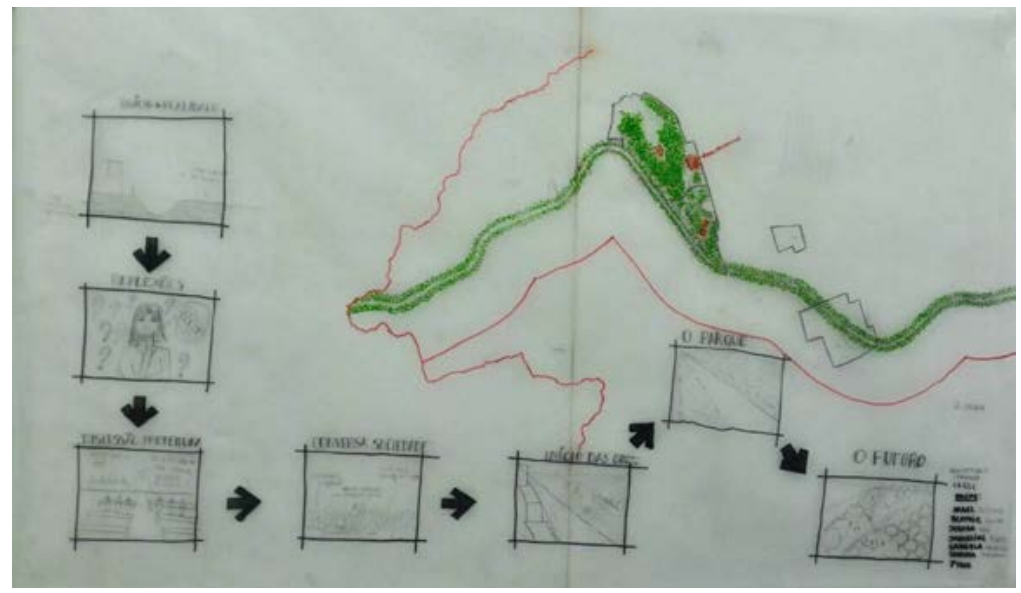

Fonte: Perceptiva elaborada a partir da proposta do grupo 2.

Para a implementação dessa proposta, algumas residências e edificações seriam desapropriadas, pois estariam em áreas irregulares, ou seja, foram construídas na faixa de 15 metros consideradas pela Lei de Parcelamento do Solo, como área não edificável.

A criação do parque, enquanto uma infraestrutura verde, instalada nas margens do rio Criciúma com a participação da população como forma de melhorar a qualidade de vida, pode propiciar efeitos positivos para o resgate da identidade do rio Criciúma em relação à cidade, além de contribuir para a melhoria da função ecológicas do rio e para a redução de impactos de mudanças climáticas no ambiente urbano.

Tais propostas foram discutidas e elaboradas em uma oficina acadêmica de curta duração, envolvendo professores e alunos de diversas áreas. Essas propostas necessitariam de estudos mais aprofundados, para verificar as suas viabilidades e inclusão de outros direcionamentos. 


\section{CONSIDERAÇÕES FINAIS}

As propostas de reintegração do rio Criciúma à paisagem urbana visam contribuir para as primeiras reflexões sobre a necessidade de a população do município ter conhecimento sobre o rio que corre confinado por entre o espaço urbano e pensar na possibilidade de vir a ter acesso e conviver com as margens e as águas do rio Criciúma. Para isso, é importante que o rio ou partes dele estejam visíveis à população na paisagem, a fim de que seja constatada a importância desse elemento hídrico na formação do espaço urbano de Criciúma e também para ser melhor fiscalizado.

Nesse sentido, é importante colocar em foco a canalização do rio Criciúma e confrontá-la com o contexto atual de alguns países da América, inclusive o Brasil, da Europa, da Ásia, que nos últimos anos estão revitalizando seus rios. Além disso, o trabalho apresentado busca despertar a população criciumense para discussões futuras mais aprofundadas sobre o tema.

Reintegrar o rio à paisagem urbana de Criciúma pelo processo de revitalização não significa dizer que o rio terá a mesma característica ambiental original, mas é um grande passo para qualificação dos espaços urbanos. Além disso, pretendeu-se despertar a população para a construção de uma cidade mais sustentável, pois os rios terão fauna e flora aquática adaptada à realidade urbana, e isso tornará Criciúma uma cidade culturalmente mais valorizada, sob o ponto de vista ambiental e ecológico.

\section{REFERÊNCIAS}

ADAMI, Rose Maria. Rio Criciúma: o rio que a cidades escondeu significados e representações na paisagem. Criciúma, SC: UNESC, 2015.

BRASIL. MinistériodoMeioAmbiente. Revitalizaçãodebaciashidrográficas. Disponível em: http://www.mma.gov.br/agua/bacias-hidrograficas/ 
revitaliza\%C3\%A7\%C3\%A3o-de-bacias-hidrogr\%C3\%A1ficas. Acesso em: 16 fev. 2017.

BENÉVOLO, Leonardo. História da cidade. 3. ed. São Paulo: Perspectiva, 2001.

COSTA, Lucia Maria Sá Antunes (Org.). Rios e paisagens urbanas em cidades brasileiras. Rio de Janeiro: PROURB/UFRJ, 2006.

GOMES, Myriam Mousinho Furtado. Meta 2010: programa estruturador do estado de Minas Gerais para a revitalização do rio das Velhas - Brasil. In: MACHADO, Antônio Thomáz Gonzaga da Matta et al. (Org.). Revitalização de rios no mundo: América, Europa e Ásia. Belo Horizonte: Instituto Guaicuy, 2010, p 20-26.

GORSKI, Maria Cecília Barbieri. Rios e cidades: ruptura e reconciliação. São Paulo: Editora Senac São Paulo, 2010.

IBGE. Instituto Brasileiro de Geografia e Estatística. Cidades. IBGE, 2010 b. Disponível em: < https://cidades.ibge.gov.br/v4/brasil/sc/criciuma/ panorama>. Acesso em: $01 \mathrm{dez} .2017$.

MACHADO, Antônio Thomáz Gonzaga da Matta et al. (Org.). Revitalização de rios no mundo: América, Europa e Ásia. Belo Horizonte: Instituto Guaicuy, 2010.

MARCONDES, Maria José de Azevedo. Cidade e natureza: proteção dos mananciais e exclusão social. São Paulo: Ed. Nobel, 1999.

PIAZZA, Walter F.; HÜBENER, Laura Machado. Santa Catarina: história da gente. Florianópolis: Lunardelli, 2003. 
SALLES FILHO, Marcelo de Paula. Rio Mosquito: a revitalização de um rio do semiárido, Minas Gerais, Brasil. In: MACHADO, Antônio Thomáz Gonzaga da Matta et al. (Org.). Revitalização de rios no mundo: América, Europa e Ásia. Belo Horizonte: Instituto Guaicuy, 2010, p.73-88.

SEPÚLVEDA, Rogério. Qual revitalização queremos? In: MACHADO, Antônio Thomáz Gonzaga da Matta et al. (Org.). Revitalização de rios no mundo: América, Europa e Ásia. Belo Horizonte: Instituto Guaicuy, 2010, p.15-16. 